\title{
ТЕНДЕНЦИИ И ПЕРСПЕКТИВЫ ФОРМИРОВАНИЯ ОБЩЕГО ФИНАНСОВОГО РЫНКА ГОСУДАРСТВ-ЧЛЕНОВ ЕАЭС *
}

\author{
(C) 2019 Алексеев Петр Викторович \\ кандидат экономических наук, ведущий научный сотрудник \\ Институт исследований международных экономических отношений \\ Финансовый университет при Правительстве Российской Федерации \\ 125993, г. Москва, Ленинградский пр-т, д. 49 \\ E-mail: palekseev@fa.ru
}

Общий финансовый рынок (ОФР) Евразийского экономического союза (ЕАЭС) является в перспективе одним из важнейших факторов успешного развития Союза. При создании ОФР важно исходить из концептуальных основ повышения интеграционного взаимодействия стран ЕАЭС, включающие четыре компонента: системную методологию, воспроизводственную теорию, идеологию и практицизм. Целостность и системность концепции формирования ОФР ЕАЭС предполагает при ее разработке опору на базовые нормативно-правовые документы, принимаемые на уровне ЕАЭС, учет национальных особенностей развития экономик, банковских и финансовых систем стран ЕАЭС, действующих концепций и стратегий развития финансовых рынков, а также использование многолетнего опыта создания европейского финансового рынка. В статье показано, что главным критерием эффективности функционирования ОФР, а также укрепления евразийской интеграции является степень ориентации финансовой политики на стимулирование экономического роста в регионе.

Ключевые слова: общий финансовый рынок, рынок банковских услуг, рынок страхования, рынок ценных бумаг, воспроизводственная теория, евразийский финансовый паспорт.

В настоящее время правительства и центральные (национальные) банки государств-членов ЕАЭС совместно с Евразийской экономической комиссией разрабатывают проект концепции формирования ОФР ЕАЭС в соответствии с распоряжением, принятым 26 декабря 2016 г. на заседании Высшего евразийского экономического совета.

Целостность и системность концепции формирования ОФР ЕАЭС предполагает при ее разработке опору на базовые нормативно-правовые документы, принимаемые на уровне ЕАЭС, учет национальных особенностей развития экономик, банковских и финансовых систем стран ЕАЭС, действующих концепций и стратегий развития финансовых рынков, а также использование многолетнего опыта создания европейского финансового рынка [1]. При разработке данной концепции целесообразно использовать концептуальные основы повышения интеграционного взаимодействия стран ЕАЭС, разработанные профессором Л.Н. Красавиной в 2016 г. и включающие следующие четыре компонента: системная методология, воспроизводственная теория, идеология и практицизм [2].

Базовые положения о создании ОФР заложены в Договоре о Евразийском экономическом союзе. Содержащийся в документе Протокол по финансовым услугам определяет направления, порядок, меры и сроки гармонизации национальных законодательств государств-членов ЕАЭС в секторах банковского и страхового рынков, а также секторе ценных бумаг (фондовом) на период до 1 января 2025 г.

Договор о ЕАЭС определяет понятие «ОФР» как финансовый рынок государств-членов, который соответствует следующим критериям:

- соблюдение гармонизированных требований к регулированию и надзору в сфере финансовых рынков государств-членов;

- взаимное признание лицензий в банковском и страховом секторах, а также в секторе услуг на рынке ценных бумаг, выданных уполномоченными органами одного государства-члена на территориях других государств-членов;

- осуществление деятельности по предоставлению финансовых услуг на всей территории Союза без дополнительного учреждения в

\footnotetext{
* Статья подготовлена по результатам исследований, выполненных за счет бюджетных средств по государственному заданию Финуниверситету.
} 
качестве юридического лица;

- административное сотрудничество между уполномоченными органами государств-членов, в том числе путем обмена информацией [3].

В настоящее время на формирование ОФР ЕАЭС оказывают сдерживающее влияние следующие факторы:

1) относительно невысокий экономический потенциал государств-членов ЕАЭС вследствие недостаточного уровня развития и конкурентоспособности их экономик, тенденции к деиндустриализации, примитивизации структуры экономик, деформации воспроизводства по линии отставания развития производственного сектора от финансового сектора;

2) незавершенность формирования единого экономического пространства, сохранение препятствий для свободного передвижения факторов производства в регионе, включая валютные ограничения;

3) существенная дифференциация в уровне развития экономик и финансовых рынков стран ЕАЭС, их структурная разнородность, различия в правовом регулировании хозяйственной дея- тельности, практике регулирования и надзора;

4) дефицит финансовых ресурсов в странах ЕАЭС, в том числе в России, в том числе вследствие оттока и бегства капиталов в различных формах; ограничительных санкций против России.

Особого внимания заслуживает существенная дифференциация в уровне развития экономик и финансовых рынков, включая его различные сегменты (банковский сектор, рынок страхования и рынок ценных бумаг), между странами. Так, например, дифференциация по уровню развития банковского сектора находит отражение в уровне кредитования юридических лиц в странах ЕАЭС: этот показатель достигает наибольших значений в Белоруссии, России и Армении и значительно меньших в Кыргызстане и Казахстане (табл. 1).

Наряду с этим, сохраняется существенная дифференциация по объему биржевых торгов на фондовых рынках: по этому показателю лидируют Казахстан и Россия, за ними со значительным отрывом следуют другие страны ЕАЭС (табл. 2).

Для разработки мер по формированию ОФР

Таблица 1. Динамика объема кредитования юридических лиц в странах ЕАЭС в 2015-2017 гг., в млн. долл. и\% к ВВП

\begin{tabular}{|c|c|c|c|c|c|c|}
\hline \multirow{2}{*}{ Страны } & \multicolumn{2}{|c|}{2015} & \multicolumn{2}{|c|}{2016} & \multicolumn{2}{c|}{2017} \\
\cline { 2 - 7 } & млн. долл. & \% к ВВП & млн. долл. & \% к ВВП & млн. долл. & \% к ВВП \\
\hline Армения & 2839,7 & 26,9 & 3416,7 & 32,3 & 3774,0 & 32,6 \\
\hline Беларусь & 23569,7 & 42,6 & 22551,9 & 47,5 & 29478,5 & 54,2 \\
\hline Казахстан & 32816,5 & 17,8 & 22257,8 & 16,2 & 23199,8 & 14,7 \\
\hline Кыргызстан & 1084,9 & 16,2 & 1203,4 & 17,7 & 1330,1 & 17,6 \\
\hline Россия & 564390,8 & 41,1 & 531870,5 & 41,3 & 659199,5 & 41,8 \\
\hline ЕАЭС & 624701,6 & 38,3 & 581282,0 & 39,0 & 716981,9 & 39,5 \\
\hline
\end{tabular}

Источник: http://www.eurasiancommission.org/ru/act/integr_i makroec/dep_stat/fin_stat/statistical publications/Documents/ finstat/finstat_2017.pdf. Дата обращения: 15.01.2019.

Таблица 2. Динамика объема биржевых торгов на фондовых рынках стран ЕАЭС в 2015-2017 гг., млн. долл. США и\% к ВВП

\begin{tabular}{|c|c|c|c|c|c|c|}
\hline \multirow{2}{*}{ Страны } & \multicolumn{2}{|c|}{2015} & \multicolumn{2}{|c|}{2016} & \multicolumn{2}{c|}{2017} \\
\cline { 2 - 7 } & млн. долл. & \% к ВВП & млн. долл. & \% к ВВП & млн. долл. & \% к ВВП \\
\hline Армения & 29,0 & 0,3 & 114,0 & 1,1 & 165,0 & 1,4 \\
\hline Беларусь & 6152,0 & 11,1 & 4814,0 & 10,1 & 4103,0 & 7,5 \\
\hline Казахстан & 116235,0 & 63,0 & 125369,0 & 91,3 & $\ldots$ & $\ldots$ \\
\hline Кыргызстан & 62,0 & 0,9 & 143,0 & 2,1 & 67,0 & 0,9 \\
\hline Россия & 338871,0 & 24,7 & 357164,0 & 27,7 & 607092,0 & 38,5 \\
\hline ЕАЭС & 461349,0 & 28,3 & 487604,0 & 32,7 & 611427,0 & 33,7 \\
\hline
\end{tabular}

Источник: http://www.eurasiancommission.org/ru/act/integr_i_makroec/dep_stat/fin_stat/statistical_publications/Documents/ finstat/finstat_2017.pdf. Дата обращения: 15.01.2019. 
ЕАЭС, на наш взгляд, целесообразно использовать концептуальные основы повышения интеграционного взаимодействия стран ЕАЭС, разработанные профессором Л.Н. Красавиной в 2016 г. и включающие следующие четыре компонента: системная методология, воспроизводственная теория, идеология и практицизм [4].

Надежной теоретической основой формирования ОФР ЕАЭС служит воспроизводственная теория, которую академик Л.И. Абалкин считал своеобразной национальной печатью российской экономической науки [5]. По мнению профессора Л.Н. Красавиной, в отличие от меновой концепции она определяет необходимость анализа прямой и обратной связи интернационализации региональной экономики с процессом воспроизводства с учетом его модификации. В условиях экономической и особенно финансовой глобализации развитие производственного сектора отстает от бурного роста финансового сектора экономики, порождая хозяйственные диспропорции [6]. В связи с этим воспроизводственный подход определяет первостепенное значение формирования экономического потенциала Евразийского союза на основе повышения эффективности процесса воспроизводства в государствах-участниках евразийской интеграции [7].

Ввиду вышесказанного очевидно, что определение ОФР, закрепленное в Договоре о ЕАЭС и основанное на критериальном подходе, не учитывает функциональной роли формируемого ОФР. С учетом этого полагаем целесообразным сформулировать и закрепить в соответствующих нормативно-правовых и концептуальных документах понятие ОФР как совокупность национальных финансовых рынков и рынка трансграничных финансовых услуг, функциональное назначение которых состоит в рациональном перераспределении финансовых ресурсов в рамках ЕАЭС в целях содействия долгосрочному инвестированию в реальный сектор национальных экономик, обеспечению их финансовой устойчивости и дальнейшему углублению региональной финансово-экономической интеграции.
Для разработки мер по формированию ОФР важно правильно определить и закрепить в нормативно-правовых и концептуальных документах цель его создания. По нашему мнению, цель создания ОФР - обеспечение роста объема, глубины и диверсификации инструментария общего рынка финансовых услуг, поэтапное устранение ограничений на пути трансграничного перераспределения финансовых ресурсов и создание благоприятных инфраструктурных, нормативно-правовых и институциональных условий для увеличения объема инвестиций в реальный сектор экономики государств-членов ЕАЭС [8].

В разрабатываемую ныне концепцию формирования ОФР будет включен ряд направлений данного процесса, в том числе обеспечение взаимного допуска участников финансовых рынков государств-членов на национальные рынки, формирование инфраструктуры, создание системы надзора за деятельностью субъектов ОФР, создание Единого биржевого пространства и т.д. [9]

В интересах обеспечения взаимного допуска участников финансовых рынков государств-членов на национальные рынки целесообразно рассмотреть вопрос о введении так называемого евразийского финансового паспорта для финансовых институтов, обеспечивающего возможность ведения бизнеса на территории всех заинтересованных стран ЕАЭС (по аналогии с европейским финансовым паспортом для банков и финансовых компаний стран Евросоюза и ЕАСТ, образующих единый внутренний рынок в составе Европейской экономической зоны, включающей 31 государство) *.

Как представляется, при разработке концепциИ ОФР ЕАЭС важно исходить из следующих условий его полноценного функционирования: а) свободное передвижение капиталов между странами с поддержанием высокого уровня денежной ликвидности рынков; б) создание новых регуляторных финансовых институтов, ослабляющих давление спекулятивных финансовых операций в ущерб цели долгосрочного финанси-

\footnotetext{
* Европейский финансовый паспорт представляет собой своего рода лицензию для финансовых институтов какой-либо из стран ЕС на ведение бизнеса на территории других стран Евросоюза в соответствии с правилами и обязательствами, устанавливаемыми европейскими регуляторами. Например, в настоящее время 5476 британских фирм имеют один или несколько финансовых паспортов на одну или несколько стран Европейского союза или Европейской экономической зоны (ЕЭ3, EuropeanEconomicArea, EEA), в которую дополнительно входят Исландия, Норвегия, Хорватия, Лихтенштейн и, по факту, Швейцария. Со стороны стран континентальной Европы около 8000 финансовых компаний имеют паспорта на ведение дел в Великобритании.
} 
рования экономического развития; в) снижение чрезмерной зависимости финансовых рынков от деятельности нерезидентов и др.

По нашему мнению, действующий Договор о ЕАЭС следует дополнить рядом нормативно-правовых документов, касающихся создания ОФР. В частности, включенные в Договор совместно регулируемые сектора финансового рынка - банковская и страховая деятельность, а также операции на рынке ценных бумаг должны быть дополнены нормативно-правовой базой, регулирующей такие важные сегменты, как кредитный, валютный рынки, рынок микрофинансирования и другие. Кроме того, должны быть комплексно проработаны вопросы совместного регулирования кросс-секторальных пересечений продуктов и услуг финансового рынка, учитывая, что все сегменты финансового рынка активно взаимодействуют друг с другом (банковское страхование, размещение в кредитных организациях средств страховых, пенсионных и других фондов коллективных инвестиций и пр.) [10].

Выбор алгоритма и приоритетов продвижения по пути к ОФР обусловлен необходимостью учета особенностей национальных экономик и финансовых систем и принятия на каждом этапе пакетов мер, адекватных достигнутому уровню финансово-экономической интеграции и готовности стран к их реализации [11]. В связи с этим принципы дифференцированного по секторам и во времени подхода к реализации проекта формирования ОФР и разноскоростного продвижения стран в этом направлении являются ключевыми для достижения позитивных результатов интеграции [12].

С учетом принципиального сходства типов классической интеграции в ЕАЭС и Европейском союзе, выстраиваемых в логической последовательности от зоны свободной торговли и таможенного союза к единому внутреннему рынку, общему финансовому рынку и экономическому союзу, а также преимущественно банкоориентированных моделей финансовых рынков в двух регионах, логично критически переосмыслить и использовать позитивные аспекты многолетнего, неоднозначного опыта ЕС по созданию европейского финансового рынка. В частности, речь может идти на начальном этапе о предоставлении финансовым институтам стран ЕАЭС «евразийского паспорта» по аналогии с «европейским паспортом» в ЕC, обеспечивающего возможность ведения ими бизнеса на территории всех заинтересованных стран ЕАЭС, а также разработке плана действий по развитию, консолидации банковского сектора стран ЕАЭС и гармонизации условий его функционирования [13].

Важнейшим направлением формирования ОФР ЕАЭС является институциональная консолидация органов межгосударственного и наднационального регулирования и надзора. В этой связи целесообразно создание Евразийского совета по финансовой стабильности на базе действующего при Евразийской экономической комиссии Консультативного комитета по финансовым рынкам с наделением его широким кругом полномочий в сфере регулирования финансовых рынков, а также наднационального надзорного органа ЕАЭС с функцией разработки свода правил и требований по вопросам регулирования деятельности участников общего финансового рынка ЕАЭС с соответствующими рекомендациями в адрес национальных и региональных институциональных структур регулирования и надзора [14].

Резюмируя вышеизложенное, следует отметить, что для правильного концептуального обоснования формирования ОФР стран ЕАЭС важно правильно определить и закрепить в соответствующих нормативно-правовых и концептуальных документах вышеприведенные понятие ОФР и цель его создания. Важно учитывать, что главным критерием эффективности функционирования банковского и страхового сегментов рынка, рынка ценных бумаг, а также укрепления евразийской интеграции является степень ориентации финансовой политики на стимулирование экономического роста в регионе. С учетом данной целевой установки и исторически сложившегося «крена» в сторону преобладающего развития в странах ЕАЭС рынка банковских услуг следует, во-первых, консолидировать банковский сектор и повысить его финансовую устойчивость и роль в экономике путем увеличения активов и капитализации банков, выравнивания регулятивных режимов в отношении участия нерезидентов в банковском секторе и, во-вторых, активизировать меры, направленные на равномерное развитие всех сегментов финансового рынка, с повышением роли рынков ценных бумаг и страховых услуг в развитии реального сектора экономики и, соответственно, увеличением их доли в структуре финансового рынка. При этом следует иметь в виду, что ба- 
зовой предпосылкой создания ОФР стран ЕАЭС на основе повышения эффективности процесса является формирование экономического по- воспроизводства в государствах-участниках евтенциала Евразийского экономического союза разийской интеграции.

\section{Библиографический список}

1. Звонова Е.А., Пищик В.Я. О концептуальных подходах к созданию общего финансового рынка государств-членов ЕАЭС // Финансы и кредит. 2018. № 1. С. 6.

2. Красавина Л.Н. Концептуальные основы повышения интеграционного взаимодействия государств-участников Евразийского экономического союза//Деньги и кредит. 2016. № 12. С. 12.

3. Договор о Евразийском экономическом союзе (Астана, 29 мая 2014 г.). Приложение 17, ст. 3 / Справочная правовая система «Гарант». Дата обращения: 15.01.2019.

4. Красавина Л.Н. Концептуальные основы повышения интеграционного взаимодействия государств-участников Евразийского экономического союза//Деньги и кредит. 2016. № 12. С. 12.

5. Абалкин Л.И. Российская школа экономической мысли: поиск самоопределения. Москва. 2000.

6. Красавина Л.Н. Контуры стратегии развития интеграции: от Евразийского экономического союза к экономическому и валютному союзу с единой валютной в аспекте опыта зоны евро // Экономические стратегии. 2015. № 7. С. 8.

7. Там же. С. 10.

8. Пищик В.Я., Алексеев П.В. Формирование общего финансового рынка государств-членов ЕАЭС//Финансовый журнал. 2017. № 5. С. 103.

9. Давтян Т.Щ. Единое биржевое пространство ЕАЭС в архитектуре общего финансового рынка Евразийского экономического союза // Международное сотрудничество евразийских государств: политика, экономика, право. 2017. № 2. С. 6.

10. Пищик В.Я., Алексеев П.В. Формирование общего финансового рынка государств-членов ЕАЭС//Финансовый журнал. 2017. № 5. С. 109.

11. De Grauwe P. Crisis in the Eurozone and How to Deal with It. CEPS Policy Brief, 2010, February 15, no. 204. URL: https;//papers.ssrn.com/sol3/Papers.cfm?abstact_id-1604453

12. Звонова Е.А., Пищик В.Я. О концептуальных подходах к созданию общего финансового рынка государств-членов ЕАЭС // Финансы и кредит. 2018. № 1. С. 12.

13. Там же. С. 12.

14. Там же. С. 13. 